\title{
EVSItalia Database of Broadleaved Deciduous Submediterranean Forests
}

\author{
Francesco Spada, Emiliano Agrillo \& Nicola Alessi
}

\begin{abstract}
A database of phytosociological relevés of Broadleaved Deciduous Submediterranean Forests of peninsular Italy (the Thyrrenian sea basin, from Liguria to Calabria including Sicilia and Sardegna) is presented (EVSItalia Database of Broadleaved Deciduous Submediterranean Forests, GIVD ID EU-IT-009). The data-set aims to store information from published phytosociological sources, in order to support ongoing reviews based on larger data-sets for comparative classification of Italian vegetation types. The database stores 733 relevés, mostly in oak forest areas dominated by Quercus pubescens and Q. cerris, from the subcoastal to the limit of beech forests in the mountain range of the Apennines and in the forests related to the syntaxa Quercion-pubescentis petreae in Sardegna. Relevés were uploaded to TURBOVEG and store information about localization (ArcGis Database) in the square of the grid of Operational Geographic Units (OGU, i.e. quadrates of the Italian floristic grid), precise GPS or toponym localization and descriptive records of locations extracted from geographical information systems. Presence-absence or quantitative matrices are produced as well. The database aims to produce data for coenological classification and parametrisation over larger areas by geostatistical analysis. This will allow to explore patterns of similarity among the distribution of different associations (chorological groups of associations, provincialism), patterns of geographic changes in community distribution along topographical gradients and to test changes in the physical scenario of selected individual communities along geographical gradients. A different insight in to the patterns of synonymy and reassessment among syntaxa on the basis of a geographical treatise is expected.
\end{abstract}

Keywords: Italian vegetation database; TURBOVEG.

GIVD Database ID: EU-IT-009

\section{EVSItalia Database of Broadleaved Deciduous Submediterranean Forests}

Scope: The data-set aims to store information from published/certified phytosociological sources in order to support ongoing reviews based on larger data-sets for comparative classification of Italian vegetation types.

Status: completed and continuing

Period: $1960-2008$

Database manager(s): Emiliano Agrillo (emiliano.agrillo@uniroma1.it); Nicola Alessi (alessinicola@hotmail.it)

Owner: [NA]

Web address: [NA]

Availability: according to a specific agreement

Online upload: no Online search: no

Database format(s): TURBOVEG, ArcGis database

Export format(s): TURBOVEG, ArcGis database

Publication: [NA]

Plot type(s): normal plots

Plot-size range: $8-500 \mathrm{~m}^{2}$

Non-overlapping plots: 733

Total plot observations: 733

Estimate of existing plots: [NA]

Number of sources: 23

Countries: IT: $70.0 \%$

Forest: [NA] — Non-forest: [NA]

Guilds: all vascular plants: $100 \%$; bryophytes (terricolous or aquatic): $5 \%$

Environmental data: [NA]

Performance measure(s): [NA]

Geographic localisation: [NA]

Sampling periods: $[\mathrm{NA}]$

Information as of 2012-07-12; further details and future updates available from http://www.givd.info/ID/EU-IT-009

Francesco Spada (francesco.spada@uniroma1.it), Emiliano Agrillo* (emiliano.agrillo@uniroma1.it), Nicola Alessi (Nicola.alessi@uniroma1.it)

Department of Environmental Biology, Sapienza University of Roma, Rome, ITALY

*Corresponding author 